\title{
Larval development of Neopisosoma neglectum Werding, 1986 (Decapoda: Anomura: Porcellanidae) under laboratory conditions
}

\author{
B. Werding \& H.-G. Müller \\ Institut für Allgemeine und Spezielle Zoologie der Justus-Liebig-Universität; \\ Stephanstraße 24, D-W-6300 Giessen, Germany
}

\begin{abstract}
The complete larval development of the porcellanid crab Neopisosoma negluctum Werding, 1986, was studied under laboratory conditions. At $27^{\circ} \mathrm{C}$, the megalopa appeared after 9 days. The development consists of a transitory prezoea, two zoeal stages and a megalopa stage. The larvae exhibit telsonal features which places them in the Petrolisthes-group of porcellanid larvae. Larval morphology gives no additional support for the status of Neopisosoma as an independent genus.
\end{abstract}

\section{INTRODUCTION}

Neopisosoma neglectum has been described recently from the northern coast of South America and the Lesser Antilles, ranging from the Golfo de Urabá (Colombia) in the west, through Santa Marta (Colombia) and Grenada to Saint Martin (Werding, 1986). The species inhabits intertidal fouling communities in heavily exposed situations. The genus Neopisosoma Haig is close to Pachycheles Stimpson and restricted to the tropics on both sides of America. It is represented in the eastern Pacific by three species and in the western Atlantic by four. As Werding (1986) pointed out, the species of Neopisosoma belont to two groups of closely related species, which are, on the other hand, close to similar groups of Pachycheles. The first group is represented in the western Atlantic by $N$. angustifrons, which is, at the same time, the only species of this genus whose larval development has already been studied (Gore, 1977). Therefore, is would be interesting to know larvae of the second group, which is represented in the western Atlantic by $N$. neglectum and two additional species. The comparison of the different Neopisosomalarvae with those of closely related Pachycheles might reveal additional criteria to be considered when the status of Neopisosoma as an independent genus is discussed (see "Discussion" in Werding, 1986).

\section{MATERIAL AND METHODS}

Ovigerous females were collected from the bay of Santa Marta (Colombia) and transported separately in small quantities of sea water to Giessen (FRG). The animals proved to be resistant to extreme changes of temperature during the journey from Santa Marta $\left(29^{\circ} \mathrm{C}\right)$ to the Giessen laboratory, with a stop over of three days at Bogotá, and 
finally with ambient temperatures as low as $17^{\circ} \mathrm{C}$. In the laboratory, the females were held individually in 400-ml beakers containing a mixture of natural and artificial seawater at a room temperature of $21^{\circ} \mathrm{C} \pm 1{ }^{\circ} \mathrm{C}$. When hatching occurred, 50 larvae were taken and placed separately in plastic dishes $(\varnothing 9 \mathrm{~cm})$, containing $50 \mathrm{ccm}$ of artificial sea water. Initially, 10 zoea I were placed in one dish and maintained in an incubator at a constant temperature of $27^{\circ} \mathrm{C}$. The cultures were exposed to light only during the daily controls. During changing of water in the containers, dead larvae and exuviae were removed, and larvae were fed with newly hatched Artemia nauplii. An additional large sample of recently settled megalopae was taken when examining the infauna of an exposed rock on the beach at Chengue Bay near Santa Marta in August 1988.

Larvae for subsequent description were stored in $70 \%$ methanol, appendages were mounted in glycerine and sealed with hot paraffine. The description of colouration and cromatophore distribution is based on living or freshly preserved animals. Carapace length was measured from the frontal region to the posteriomedial margin of the carapace.

\section{RESULTS}

\section{Rearing experiment}

Most of the larvae had just passed the prezoeal stage when encountered in the receptacle where the female was maintained. Neopisosoma neglectum reaches the megalopal stage after 9 to 10 days of rearing at $27^{\circ} \mathrm{C}$. The graph in Figure 1 shows larval survival and molting times. None of the remaining megalopae molted to the subsequent

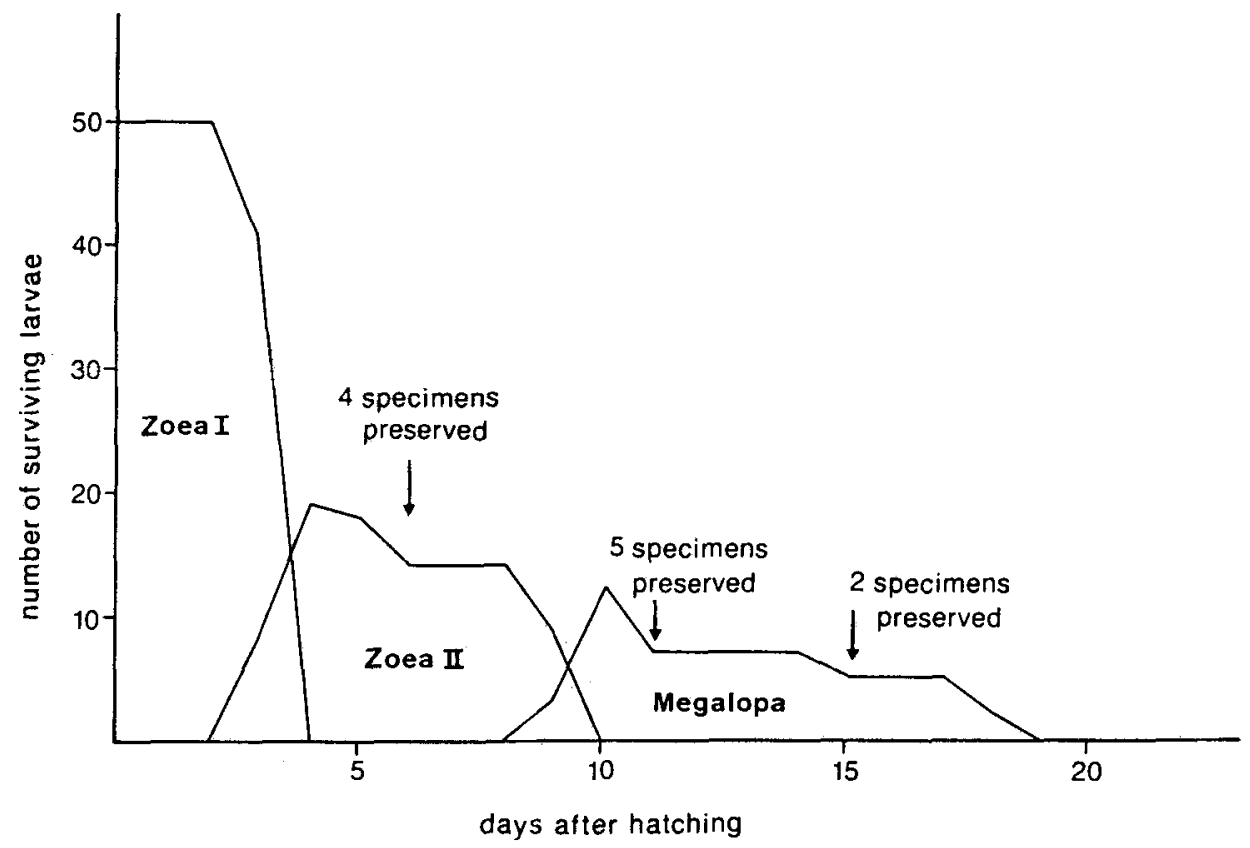

Fig. 1. Survival of Neopisosoma neglectum larvae reared at $27^{\circ} \mathrm{C}$ in the laboratory 
stage as shown in Figure 1; thus, the complete duration of the megalopa stage has not been established.

\section{DESCRIPTION OF LARVAE}

Zoe a I (Figs 2A, $3 \mathrm{~A}-\mathrm{H}$ ).

Carapace length $-1.4 \mathrm{~mm}$ (ten specimens examined).

Typical porcellanid zoea. Rostral spine about double length of carapace, armed densely with small, foreward directed spines. Posterior spines about $2 / 3$ of carapace length, curved downward, ventrally armed for about $1 / 2$ of the length with some wide-set, downward directed spines.

Antennule (Fig. 3A). Unsegmented with three terminal aesthetascs and two setae.

Antenna (Fig. 3B). Biramous, endopodite fused with protopodite, simple; expodite mobile, about $1^{1 / 2}$ times as long as endopodite, pointed and with one subterminal spine.

Mandibles (Fig. 3 C). Assymetric, strongly toothed.

Maxillule (Fig. 3D). Endopodite unsegmented, bearing four terminal setae, one of them simple. Coxal endite with one simple and four spinous massive processes and three simple setae. Basal endite with seven setae, three of them simple.

Maxilla (Fig. 3 E). Endopodite singly segmented, with 8-9 setae, four of them simple. Coxal endite with seven and five, basal endite with four and five setae on proximal and distal lobes, respectively, placed as illustrated. Scaphognathite with six long plumose marginal setae and an apical one.

Maxilliped I (Fig 3 F). Biramous, coxopodite naked. Basipodite with four groups of 2, 2, 3 and 3 setae on the inner margin. Endopodite four-segmented with 2, 3,2+3 and 6 setae from proximal to distal segment. An additional large seta on the opposite side of terminal segment. Exopodite two-segmented with four terminal natatory setae.

Maxilliped II (Fig. 3G). Coxopodite naked. Basipodite with 1 and 2 ventral setae. Endopodite four-segmented with 2, 2, $1+2$ and 5 setae. An additional large seta on the oposite side of terminal segment. Exopodite two-segmented with four terminal natatory setae.

Maxilliped III and pereiopods, undeveloped buds which grow as stage progresses.

Abdomen composed of five somites. The third and the fourth with a pair of small, fifth with a pair of prominent lateral spines.

Telson (Fig. $3 \mathrm{H}$ ) with a pair of lateral spines which are accompanied by a small plumose seta each. Five pairs of long plumose setae with distinct hook-like spinules at the tips of every one of them.

Colouration: Carapace translucent. Rostral spine translucent at proximal half, distally passing through a faintly orange coloured zone, a whitish-opaque one, and ending in an intensly orange colored tip. A large red-orange spot around oesophagus and foregut. Basipodites of maxillipeds red. A starlike red chromatophore at each side of carapace. Abdomen bright blue.

Zoea II (Fig. 2 B, Fig, 4 A-H).

Carapace length $1.9 \mathrm{~mm}$ (four specimens examined).

Larger than first zoea. Rostral spine curved upward, reaching about 1.9 of carapace length. Posterior spine is very short compared with first zoea, reaching less than $1 / 4$ of carapace length, the spinulation of rostral and posterior carapace-spine is less accentuated than in zoea I. 

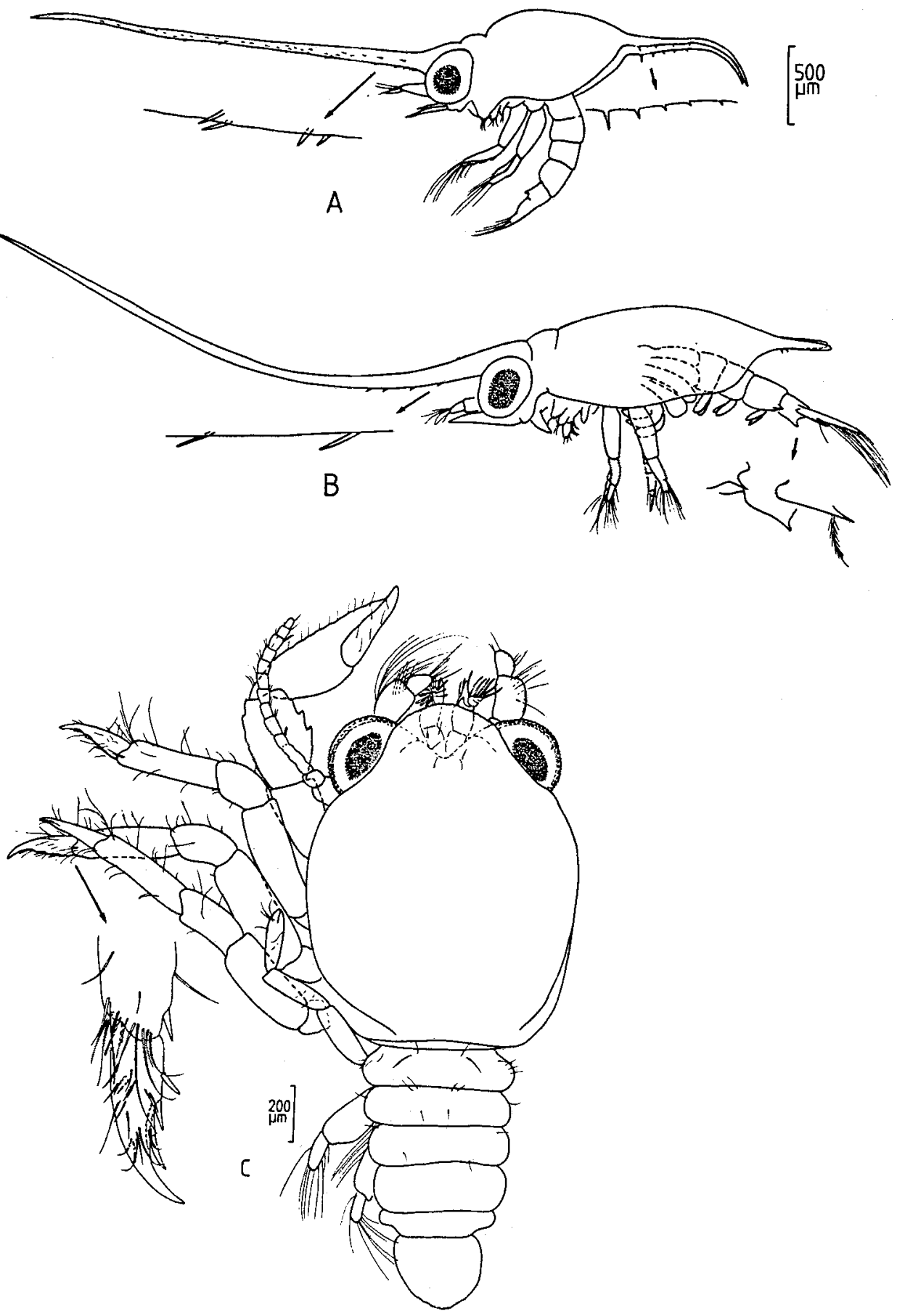

Fig. 2. Neopisosoma neglectum. A: Zoea I; B: Zoea II; C: Megalopa 

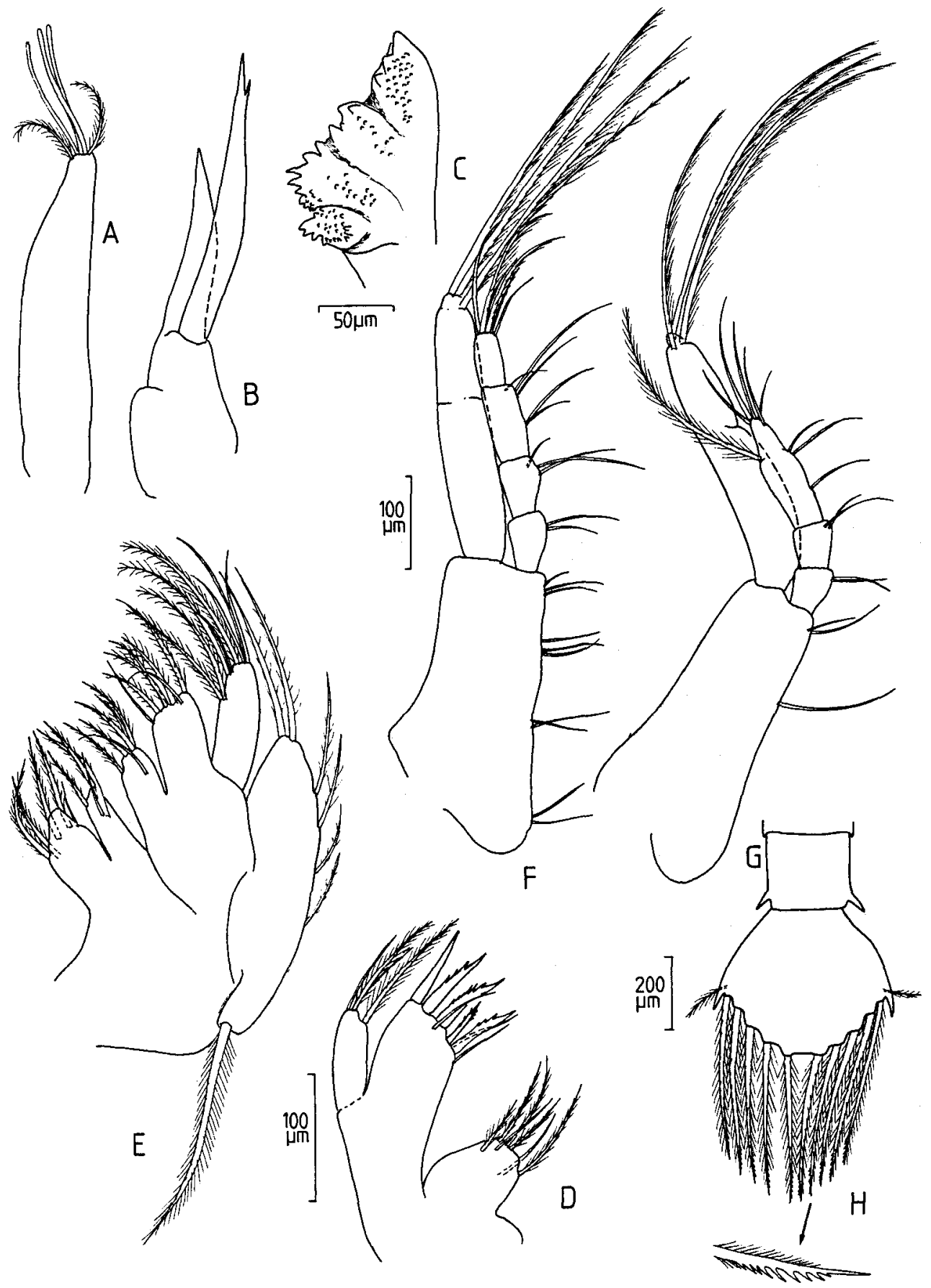

Fig. 3. Neopisosoma neglectum. First zoeal appendages and tail fan. A: antennule; B: antenna; C: mandible; D: maxillule; E: maxilla; $F$ : maxilliped $\mathrm{I}_{i} \mathrm{G}$ : maxilliped $\mathrm{II} ; \mathrm{H}$ : tail fan with detail of seta ornamentation 


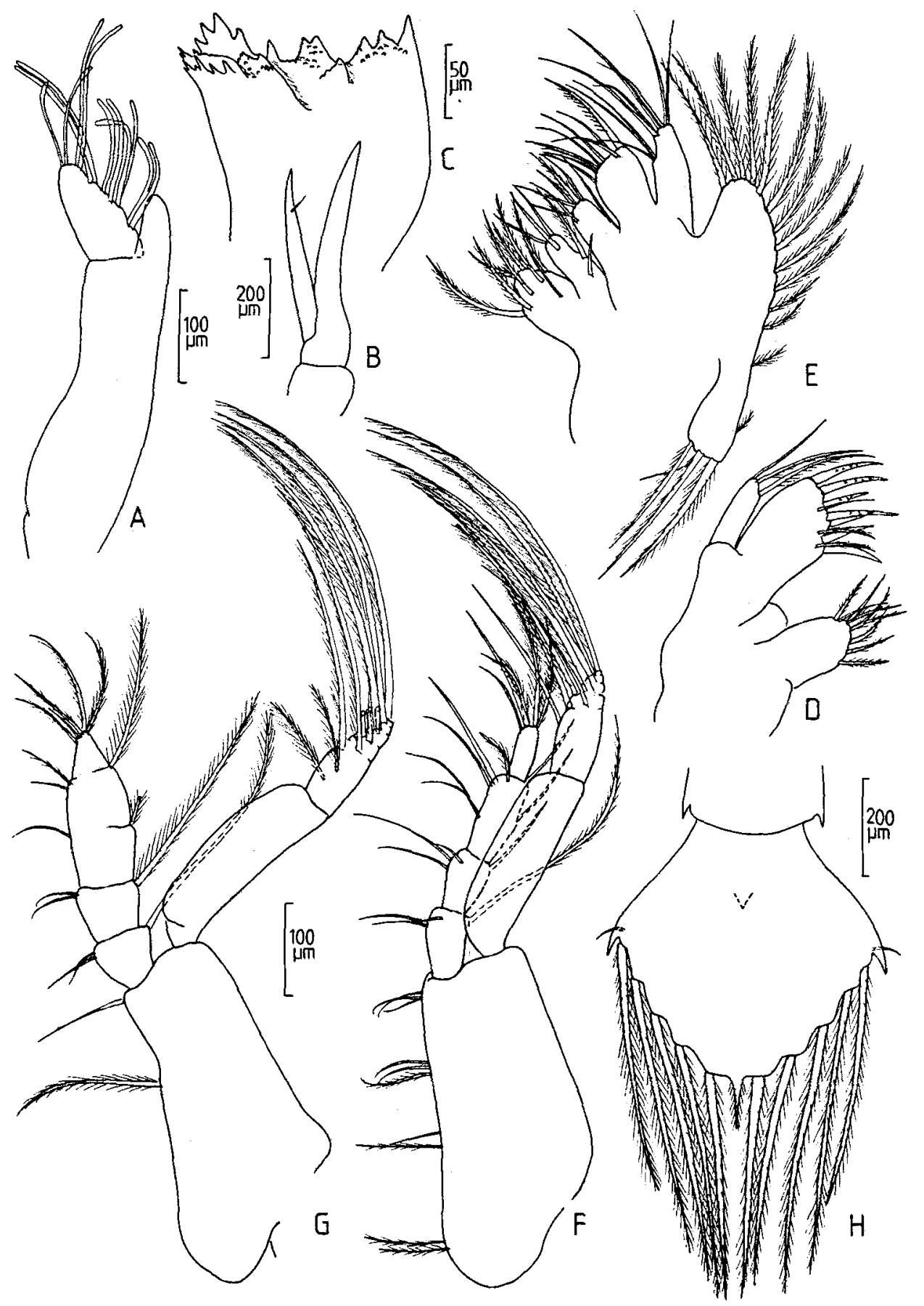

Fig. 4. Neopisosoma neglectum. Second zoeal appendages and tail fan. A: antennule; B: antenna; C: mandible; D: maxillule; E: maxilla; F: maxilliped $I_{i} G$ : maxilliped II; $H$ : tail fan 
Antennule (Fig. 4 A). Biramous, endopodite fused to protopodite, about $1 / 2$ length of exopodite. Exopodite with 10 lateral and 3 terminal aesthetascs and 2 terminal setae.

Antenna (Fig. 4 B). Biramous, endopodite longer than exopodite, pointed. Exopodite pointed, with one subterminal seta.

Mandibles (Fig. 4 C). As in first zoea but with additional palp.

Maxillule (Fig. 4 D). Similar as in first zoea. Endopodite bearing three terminal setae, one of them simple. Coxal endite with six massive processes and three setae, one of them simple; basal endite with nine setae, three of them simple.

Maxilla (Fig. 4 E). Single segmented endopodite with 8 setae. Coxal endite with 5 and 8 , basal endite with 9 and 9 setae on proximal and distal lobes, respectively, placed as illustrated. Scaphognatite with 14-15 setae on margins and three long plumose setae distally.

Maxilliped I (Fig. 4 F). Setation in coxopodite unchanged as compared with first zoea. Each endopod segment with one plumose dorsal seta. Exopod with 8-9 long natatory setae.

Maxilliped II (Fig. 4 G). Setae of basis unchanged as compared with zoea I. Endopod now with a long plumose dorsal seta on each segment additionally. Exopod with up to ten terminal natatory setae.

Maxilliped III and pereiopod, elongated buds which grow as stage progresses.

Abdomen similar to that in first zoea, but with developing pleopod buds on somites 2-5.

Telson (Fig. $4 \mathrm{H}$ ) with setation almost identical to foregoing stage but with an additional median spine. Hook-like spinulation of terminal setae less pronounced than in first zoea.

Colouration: Similar to stage I but less intense.

Me gal op a (Fig. 2C), Fig. 5A-H, Fig. 6 A-H).

Carapace $1.06-1.14 \mathrm{~mm} \times 0.95-0.99 \mathrm{~mm}$ ( 7 cultivated and 38 captured specimens examined).

Crablike, carapace suboval, inflated; without spines and with only few scattered hairs. Orbitae well defined, frontal region rounded, slightly produced beyond eyes, anterior margin slightly roughened.

Epimera separated but no membraneous areas posterior to epibranchial region.

Antennule (Fig. 5 A). Peduncle three segmented, basal segment rounded, serrate on upper margin with some scattered short setae. Third segment with one seta near base of each ramus. Lower ramus three-segmented with two, 1 and 8 setae, respectively. Upper ramus 5-segmented with the following sequence in aesthetascs: 1 row (4), 2 rows (4, $2+1$ seta), 2 rows $(2,2+1$ seta at opposite side) one row (2), fifth segment with three smaller subterminal setae and a long terminal one.

Antenna (Fig. 5B). First two movable segments with denticulation as shown in the figure. Flagellum with 15 segments, setation as drawn.

Mandible (Fig. 5 C). Palp 3-segmented, first segment bearing 2 spinules, second unarmed, third with 8 spinules as shown in figure.

Maxillule (Fig. 5D). Exopodite unsegmented, with a single subterminal seta. Basal endite with 16 short spines and 6 setae. Coxal endite with 23 spines and setae, endite extended to a round hair-fringed lobe with a single seta near base.

Maxilla (Fig. 5E). Endites with densely set spines and setae partly feathered. 


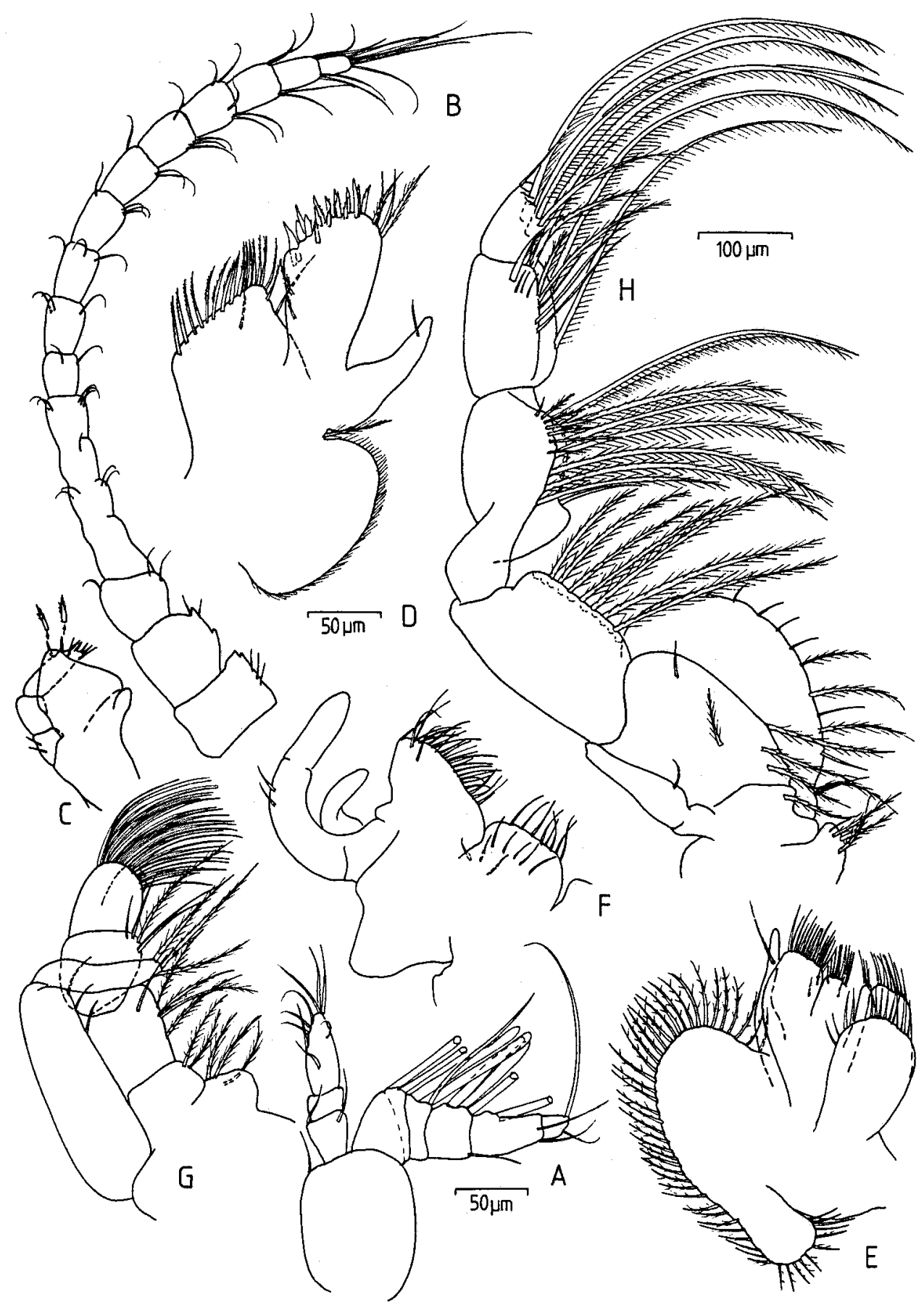

Fig. 5. Neopisosoma neglectum. Megalopal sensory and feeding appendages. A: antennule; B: antenna; C: mandible; D: maxillule; E: maxilla; F: maxilliped I; G: maxilliped II; H: maxilliped III 

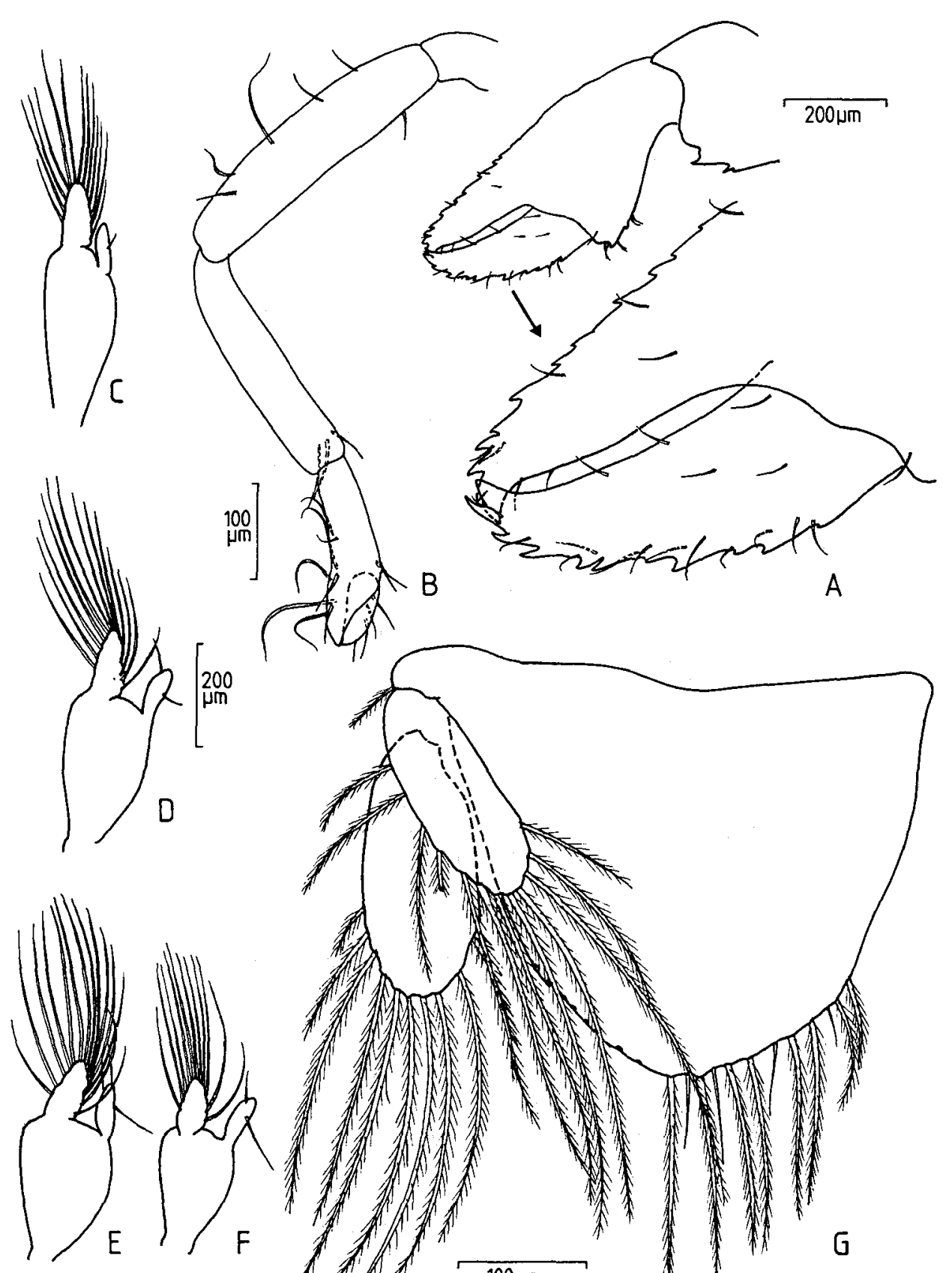
Endopod unsegmented with one large subterminal seta; scaphognatite with 50-56 soft plumose setae around outer margin.

Maxilliped I (Fig. 5F). Basis divided into two lobes with 15-16 setae on proximal and 28-30 on distal lobe. Endopod and exopod unsegmented, latter with two short lateral setae.

Maxilliped II (Fig. 5 G). Endopod 5-segmented with numerous plumose setae, progressing distally as follows: $5,5,5$ at first to third segment, more than 20 at fourth and about 25 at terminal segment. Exopod 2-segmented, proximal segment bearing 3 setae on its inner distal surface, distal segment with 2 large terminal setae.

Maxilliped III (Fig. $5 \mathrm{H}$ ). Biramous, exopodite indistinctly two segmented. Endopod 5 -segmented. Merus with a double row of long filtering setae $(7+10$ on outer and inner margin, respectively). Following segments similar (carpus $10+8-9$, propodus $11+7$, dactylus $10+6$ ) but with some additional smaller setae.

Pereiopods (Fig. 6 A,B). Ambulatory legs setose, merus unarmed, propodus with two single and a pair of distal movable spines as in adults, dactylus with three movable spines. Fifth pereiopod chelate, gape dentate, with 5-6 curved cleaning setae plus other setae. Cheliped carpus with two or three spiny teeth, outer margins of both fingers armed with curved teeth.

Pleopods (Fig. 6 C-F). Four pairs of simple biramous pleopods present. Exopod with variable number of setae (11-14). Endopod with 1-3 small setae and with 3-4 minute hooks.

Tail fan (Fig. 6G). Telson with 7-8 marginal long plumose setae at either side and a smaller number of shorter setae interspersed between these. Uropod exopodite with 9-10 long setae, endopod 8-9.

Colouration: Megalopa translucent, yellowish-orange. Numerous red cromatophores, especially crowded at orbital margin and infraorbital margin and at the lateral margins of carapace, progressing distally. Walking legs with one red cromatophore distally at merus and carpus, various cromatophores dispersed in propodus. 3-5 at distal part of carpus of cheliped, manus of same with 3-4 red cromatophores near articulation with carpus, 5-7 in front of the dactyl articulation and a singular one in the middle of dactylus. Buccal cavity with some dispersed red cromatophores.

\section{DISCUSSION}

The larval cycle of Neopisosoma neglectum passes through the two zoeal stages in only ten days under the described experimental conditions. The mean surface water temperatures in the Santa Marta bay ranges from $28.8^{\circ} \mathrm{C}$ during the rainy season (May to November) and $25.5^{\circ} \mathrm{C}$ during the dry season (Salzwedel \& Müller, 1983). Consequently, we suppose that, under natural conditions, the two larval stages do not spend essentially more than some ten days in the plankton. $N$. neglectum settles as megalopa, as quantitative collections in the Santa Marta area have shown (own unpublished observations). Megalopae of porcellanids are seldom found in the plankton (Lebour, 1943; Wear, 1964) and the swimming period seems to be essentially restricted to the zoeae and perhaps to a small part of megalopal life. Thus, the time of larval spreading seems to be limited in N. neglectum to two or at maximum three weeks. This limitation, in combina- 
tion with the extreme habitat requirements may be the main reason for the restricted distribution of the species in the southern and southwestern Caribbean Sea.

Lebour (1943) subdivided porcellanid larvae using telsonal and mandibular features of zoea. In her Petrolisthes-group, the median pair of telsonal setae are placed on the central prominence. An additional central spine occurs on the telson of zoea II. Additionally, in the first zoeae of the Petrolisthes-group the mandibles lack palps. For the larva of $N$. angustifrons, Gore (1977) stated that it belongs to the Petrolisthes group of larvae. The larvae of $N$. neglectum also agree with the Petrolisthes-type as expected.

When Konishi (1987) described the larval development of the western-Pacific species Pachycheles stevensii Stimpson, he compared all known larvae of the genus Pachycheles and Neopisosoma. He exposed the spinulation of the antennal exopod as a possible diagnostic character and discussed its value, even for separation of Neopisosoma from Pachycheles as was suggested by Gore (1977) for the case of $N$. angustifrons. All of the compared species display from 3 to 4 such spinules, arranged in different sequences. In contrast, $N$. neglectum differs from all those species in having only one subterminal spinule and may be distinguished by that character from the other known species of the group. At the same time, the spinulation of the antennal exopod can no longer be considered a significant character on the generic level.

A second feature which distinguishes $N$. neglectum from all other species under discussion is the spinulation of the telsonal setae. Gore (1977) and Konishi (1987) emphasize the presence of hook-like spinules on the tips of the outer two pairs of plumose setae as a common feature of all known species of the group. In contrast, $N$. neglectum larvae exhibit such structures along the distal portion of all terminal setae.

The description of larval development is often stated as a requirement for the identification of larvae caught in the plankton. However, it is only in the region of the present study, which is the coast around Santa Marta, that nine species of the two discussed genera are known to occur (Werding, 1977, 1978). In only three of them is the larval morphology described. In addition, a determined larva would have to be distinguished, in a given case, from nearly 20 additional larvae species of the Petrolisthes-type. Even though there are other morphological features such as rostral and carapace spine form, relative length, or the colouration of living larvae that might offer more handy criteria for the separation of some larvae, in practice it will prove to be unrealistic to carry out larval identification from plankton samples. On the other hand, future descriptions of additional species might reveal additional criteria for a clearcut separation of genera.

At the species level, the study of larval characters in closely related species might also reveal additional criteria for their separation. In the case of Megalobrachium poeyi (Guérin) and $M$. pacificum Gore and Abele, Gore (1971) suggested that on the basis of differences in the larvae, the Pacific and Atlantic populations, which had been considered conspecific, might be distinct species. Later, Gore \& Abele (1973) confirmed the existence of two distinct species.

The genus Neopisosoma was established by Haig (1960) in order to separate from Pachycheles some species which differ in the structure of the epimera of the carapace. While the side walls of Pachycheles consist of a large anterior piece and a posterior portion, composed of one or more pieces separated by membranous interspaces, in Neopisosoma the posterior portion is occupied by a membrane only. Haig (1960) herself questioned the status of the new genus, suggesting that it might prove to be a subgenus 
of Pachycheles after a revision of that genus on a worldwide basis. The same question was discussed by Gore (1977) when he compared the larvae of $N$. angustifrons with those of Pachycheles. When describing N. neglectum for the first time, Werding (1986) treated the same problem, considering that the presence of epimeral fragments behind the frontal piece in Pachycheles seems to be a character of degree which exhibits a wide range of reduction in different species. Comparing the larval features of $N$. neglectum with those of $N$. angustifrons it becomes evident that the larval morphology, as known at the moment, gives no additional support for the status of Neopisosoma as an independent genus.

Acknowledgements. We thank Dr. Hernando Sanchez, Director of the Instituto de Investigaciones Marinas de Punta de Betín (INVEMAR), Santa Marta, Colombia for providing space and facilities for carrying out the collection of specimens.

\section{LITERATURE CITED}

Gore, R. H., 1971. Megalobrachium poeyi (Crustacea, Decapoda, Porcellanidae): Comparison between larval development in Atlantic and Pacific specimens reared in the latoratory. - Pacif. Sci. $25,404-425$.

Gore, R. H., 1977. Neopisosoma angustifrons (Benedict, 1901): The complete larval development under laboratory conditions, with notes on larvae of the related genus Pachycheles (Decapoda Anomura Porcellanidae). - Crustaceana 33, 284-300.

Gore, R. H. \& Abele, L. G., 1973. Three new species of porcellanid crabs (Crustacea, Decapoda, Porcellanidae) from the bay of Panama and adjacent Caribbean waters. - Bull. mar. Sci. 23, $559-573$.

Haig, J., 1960. The Porcellanidae (Crustacea: Anomura) of the eastern Pacific. - Allan Hancock Pacif. Exped. 24, 1-440.

Konishi, K., 1987. The larval development of Pachycheles stevensii Stimpson, 1858 (Crustacea: Anomura: Porcellanidae) under laboratory conditions. - J. crust. Biol. 7, 481-492.

Lebour, M. V., 1943. The larvae of the genus Porcellana (Crustacea, Decapoda) and related forms. J. mar. biol. Ass. U. K. 25, 721-737.

Salzwedel, H. \& Müller, K., 1983. A summary of meteorological data for the bay of Santa Marta, Colombian Caribbean. - An. Inst. Invest. mar, Punta de Betín, 13, 67-84.

Wear, R. G., 1964. Larvae of Petrolisthes elongatus (Milne Edwards, 1837). (Crustacea, Decapoda, Anomura). - Trans. R. Soc. N. Z. 5, 39-53.

Werding, B., 1977. Los porcelánidos (Crustacea: Anomura: Porcellanidae) de la región de Santa Marta, Colombia. - An. Inst. Invest. mar, Punta de Betín 9, 173-214.

Werding, B., 1978. Los porcelánidos (Crustacea: Anomura: Porcellanidae) de la región de Acandí (Golfo de Urabá), con algunos encuentros nuevos de la región de Santa Marta (Colombia). - An. Inst. Invest. mar, Punta de Betín 10, 213-221.

Werding, B., 1986. Die Gattung Neopisosoma Haig, $1960 \mathrm{im}$ tropischen Westatlantik, mit der Beschreibung von Neopisosoma neglectum spec. nov. und Neopisosoma orientale spec. nov. (Crustacea: Anomura: Porcellanidae). - Zool. Meded. 60 (11), 159-179. 